\title{
JuRisdiction under the Hague Choice of Courts Convention: \\ Its Likely Impact on Australian Practice
}

MARY KEYES*

\section{A INTRODUCTION}

The practice of the Australian courts in the area of enforcement of arbitration agreements has significantly changed over the course of the last several decades. Arbitration agreements are now likely to be enforced by staying Australian proceedings which are brought in breach of those agreements. The New York Convention, ${ }^{1}$ and a significant change in attitude of many Australian judges towards arbitration, are credited with this change. It is widely agreed that arbitration and jurisdiction agreements should be treated similarly, and that the justifications for the enforcement of arbitration agreements apply with equal force to the enforcement of jurisdiction agreements. In Australian litigation, jurisdiction agreements are not treated in the same way as arbitration agreements. Recent experience demonstrates that Australian courts are much more likely to retain jurisdiction where the parties have agreed to litigate in a foreign court, than they are to retain jurisdiction in the face of an effective agreement to arbitrate. The practice of Australian courts in the area of enforcement of jurisdiction agreements is not only in

\footnotetext{
* Associate Professor, Griffith Law School. I thank Tel Bodiam for research assistance; Professor Reid Mortensen for arranging the Colloquium on the Hague Choice of Courts Convention, at which an earlier version of this article was presented; and two anonymous referees for their detailed suggestions. This article was published in (2009) 5 Journal of Private International Law 181-211.

1 The Convention on the Recognition and Enforcement of Foreign Arbitral Awards 1958 (referred to as the New York Convention).
} 
contrast to the practice of the same courts in the treatment of arbitration agreements, but also to the practice of foreign courts in the treatment of jurisdiction agreements. ${ }^{2}$

This article accepts as its starting point that there are compelling reasons for the enforcement of the parties' agreements. Section B of this article outlines the justifications for enforcing party agreements in arbitration and jurisdiction, and describes the circumstances in which party agreements should yield to other concerns. In section C, I describe the current Australian law concerning the effect of an arbitration agreement in international litigation. This section also explains the Australian law on the effect that is given to effective foreign jurisdiction agreements in jurisdictional disputes. This section presents data on the practices of the Australian superior courts in dealing with jurisdictional disputes which involve effective arbitration and choice of courts agreements.

Section D outlines the jurisdictional principles of the Hague Convention on Choice of Courts Agreements, ${ }^{3}$ focusing on the changes that those principles would make to the Australian law, if the Convention were to be adopted in Australia. Section E is a conclusion, which endorses the Hague Convention, as being likely to improve the enforcement of jurisdiction agreements in litigation in the Australian courts.

\footnotetext{
2 Briggs recently stated that it is rare for English courts to exercise jurisdiction where the defendant applies for a stay, on the basis of a foreign jurisdiction agreement: A Briggs, Agreements on Jurisdiction and Choice of Law (Oxford, Oxford University Press, 2008), 52.

3 The Hague Convention on Choice of Courts Agreements 2005, adopted at the $20^{\text {th }}$ Session of the Hague Conference on Private International Law (referred to as the "Hague Convention"). The scheme of the Convention is that it enacts rules of jurisdiction, in relation to chosen and non-chosen courts; and it requires recognition of judgments which are given in conformity with its rules of jurisdiction. The issue of recognition of judgments is beyond the scope of this article.
} 


\section{B Party Autonomy and Its Limits}

It is generally accepted that jurisdiction and arbitration agreements should be treated identically for most purposes. ${ }^{4}$ In particular, the same arguments in favour of enforcing agreements apply both to arbitration and to jurisdiction agreements. The justifications for enforcing mutual agreements as to jurisdiction and arbitration are widely agreed to be compelling. The fundamental justification is that the parties' freedom to contract should be respected by enforcing their agreements. ${ }^{5}$ This gives effect to certainty and predictability, which are essential to supporting international trade and commerce. Upholding the parties' agreements as to venue and type of dispute resolution should simplify and discourage ${ }^{6}$ litigation about venue and type of dispute resolution, and this should save both public and private costs. Von Mehren and Trautman note that consent is "an easily administered and relatively precise test" of jurisdiction. ${ }^{7}$ Most legal systems recognise these virtues, so consent is an internationally uncontroversial basis of jurisdiction. ${ }^{8}$

Many writers agree that it is not appropriate to apply paternalistic or parochial presumptions as to the enforceability of jurisdiction and arbitration agreements in international commercial contracts. ${ }^{9}$ If the parties have mutually agreed on venue or type of dispute resolution, then the agreement should be enforced, unless the consequences

4 AS Bell, Forum Shopping and Venue in Transnational Litigation (Oxford, Oxford University Press, 2003), ch 5; PE Nygh, Autonomy in International Contracts (Oxford, Clarendon, 1999), 24 (in principle, arbitration "presents much the same issues as choice of court"); FAI General Insurance Co Ltd v Ocean Marine Mutual Protection and Indemnity Association (1997) 41 NSWLR 559, 567. As to the relevant distinctions, see Briggs, supra n 2, 137-139.

Williams v Society of Lloyd's [1994] 1 VR 274, 321.

Bell, supra n 4, 276, 281.

AT von Mehren and D Trautman, "Jurisdiction to Adjudicate: A Suggested Analysis" (1966) Harvard Law Review 1121, 1138.

8 A Lowenfeld, International Litigation and the Quest for Reasonableness (Oxford, Clarendon, 1996), 200 ("support of party autonomy is so widespread that it can fairly be called a rule of customary law").

9 AA Ehrenzweig, "Adhesion Contracts in the Conflict of Laws" (1953) 53 Columbia Law Review 1072, 1076. Different considerations apply in non-commercial contracts, which are beyond the scope of this paper. For detailed treatment of that issue, see J Hill, Cross-Border Consumer Contracts (Oxford, Oxford University Press, 2008). 
of that preference were unforeseeable at the time the agreement was reached, ${ }^{10}$ or unless the parties are genuinely unable to get a fair trial (or by analogy, presumably, arbitration) for exceptional reasons. ${ }^{11}$

\section{The Limits of Autonomy}

Briggs proposes that as a matter of principle, "the degree to which the law should intrude on or overrun these private agreements should be no more than is necessary to serve or secure a broader public interest." ${ }^{12}$ In general, there are two groups of public interests which mark out the limits of autonomy in the context of international commercial agreements on arbitration and jurisdiction. ${ }^{13}$ The first group is comprised of the public interests that are expressed in mandatory laws of the forum. This is a controversial, nascent area of law in Australia. For the purposes of this article, it is sufficient to note that some Australian courts perceive that they are constitutionally obliged to ensure the application of Australian legislation, ${ }^{14}$ where it enacts a strong public interest, ${ }^{15}$ even in international commercial disputes.

The second group consists of public interests in ensuring the efficient, effective and orderly resolution of disputes. This interest is manifest in the courts' concerns to minimise the private costs associated with dispute resolution, and to avoid a multiplicity of resolutions in different venues, and the unattractive prospect of inconsistent awards or

\footnotetext{
10 Bell, supra n 4, 325-326.

$11 \quad$ Ibid, 328.

12 Briggs, supra n 2, 12.

13 There are obvious public interests that arise in international contracts involving vulnerable contracting parties, such as consumers and employees, but these types of contracts are beyond the scope of this article. This issue has attracted much less attention in Australia than in other jurisdictions, but see Quinlan v SAFE International Försäkrings AB (2006) 14 ANZ Ins Cas 61-693.

14 The majority in Akai v The People's Insurance Company held that in some circumstances, Australian courts might also be required to give mandatory effect to Australian case law: Akai Pty Ltd v The People's Insurance Company Ltd (1996) 188 CLR 418, 445 ("Akai"). There is no case that has applied that aspect of Akai.

15 The cases are unclear in identifying what constitutes such an interest. In Akai, the majority stated that a stay in favour of an exclusive jurisdiction clause "may be refused where the foreign jurisdiction clause offends the public policy of the forum whether evinced by statute or declared by judicial decision": (1996) 188 CLR 418, 445.
} 
judgments. Bell notes that the objective of upholding agreements as to forum or arbitration "may serve to fracture or fragment the dispute resolution and the policy of resolving all disputes between multiple parties in one forum may trump the policy of holding a subset of those parties to their contractual bargain." ${ }^{\prime 16}$ In Donohoe v Armco Inc, Lord Bingham noted that the English courts may not enforce a choice of court agreement where the dispute involves third parties, not bound by the jurisdiction agreement, or other matters, not within the scope of the jurisdiction agreement. ${ }^{17}$ The House of Lords in that case did not enforce an express choice of English courts, because in the circumstances "the interests of justice are best served by the submission of the whole dispute to a single tribunal which is best fitted to make a reliable, comprehensive judgment on all the matters in issue."18

\section{The Current Australian Law on Jurisdiction and}

\section{Arbitration AgreEMENTS}

This section describes the current principles applicable to determine whether the Australian courts should stay proceedings brought in breach of arbitration and foreign jurisdiction agreements. It also considers how those principles are applied in practice in litigation in the Australian superior courts.

\section{International Arbitration Agreements in Australian Litigation}

The Convention on the Recognition and Enforcement of Foreign Arbitral Awards (the

New York Convention) relevantly requires that the courts of a member state must stay proceedings brought in breach of an international arbitration agreement, unless there are

16 Bell, supra n 4, 282.

17 Donohoe v Armco Inc [2002] 1 All ER 749, [27] per Lord Bingham. See similarly Bouygues Offshore SA $v$ Caspian Shipping Co (No.s 1, 3, 4 and 5) [1998] 2 Lloyd's Rep 461.

18 Donohoe v Armco Inc [2002] 1 All ER 749, [34]. 
exceptional circumstances. ${ }^{19}$ Australia is a party to the New York Convention, which is given effect in Australia in the International Arbitration Act 1974 (Cth). The Act operates in two ways, both of which emphasise the parties' agreement, and minimise the role of national law and policy in diminishing the effectiveness of that agreement. First, the Act requires an Australian court to stay proceedings brought in breach of an international arbitration agreement, insofar as the matters in dispute in the litigation are capable of settlement by arbitration, ${ }^{20}$ unless the agreement is null and void, inoperative or incapable of being performed. ${ }^{21}$ Second, the Act requires that Australian courts enforce arbitral awards to which the New York Convention applies. ${ }^{22}$ This article is only concerned with the first aspect of the legislation; that is, the requirement that Australian courts stay proceedings brought in breach of an agreement to arbitrate. In the next part, the Australian case law on the interpretation and application of the Act, particularly on the jurisprudence concerning the requirement of whether a matter is capable of settlement by arbitration, whether the agreement is null and void, inoperative or incapable of being performed, is critically examined, in order to indicate the likely interpretation of similar provisions in the Hague Convention, which are based on the New York Convention.

\section{(a) The Australian Courts' Practices in Enforcing Arbitration Agreements}

In a majority of the recent Australian cases, the courts stay proceedings in favour of arbitration, focusing strictly on the terms of the International Arbitration Act and of the arbitration agreement. The courts quite correctly do not refer to or rely upon the factors

\footnotetext{
19 The New York Convention also requires the courts of member states to give effect to international arbitral awards, and permits non-recognition in exceptional circumstances. This aspect of the Convention is beyond the scope of this article.

20 International Arbitration Act 1974 (Cth) s 7(2)(b).

21 International Arbitration Act 1974 (Cth) s 7(5).

22 International Arbitration Act 1974 (Cth) s 8.
} 
that are relevant to determining whether a stay should be granted in the courts' general discretion, ${ }^{23}$ although the governing law is often identified.

The exceptions to enforcement that are most commonly invoked by parties seeking to avoid the effect of an agreement to arbitrate include that the other party's right to seek a stay of proceedings in favour of arbitration has been waived with the result that the agreement is inoperative; that some of the claims are not capable of settlement by arbitration; and less commonly, that the agreement is null and void.

\section{(i) Inoperative agreements: waiver}

It is sometimes argued that the party seeking a stay of proceedings in favour of an arbitration agreement has waived its right to seek such a stay, because of its participation in local litigation or for other reasons. ${ }^{24}$ Waiver, if established, renders the arbitration agreement "inoperative" for the purposes of s 7(5) of the International Arbitration Act. ${ }^{25}$ In order to establish waiver of the right to seek a stay, it must be shown that there was "an irrevocable abandonment of the right under the arbitration agreements to seek a stay of the curial proceeding and a reference to arbitration", ${ }^{26}$ which was intentional and made with knowledge of the course of action foregone (waiver in the "strong sense") or "an adoption, over [a] substantial period of time, of a position inconsistent with a referral

\footnotetext{
23 That is, on the grounds of forum non conveniens. The connecting factors identified as relevant to determining the natural forum by Lord Goff in Spiliada Maritime v Cansulex [1987] AC 460, 478, were adopted in Australian law: Voth v Manildra Flour Mills Pty Ltd (1990) 171 CLR 538, 564-564. These factors are also often identified in cases involving exclusive foreign jurisdiction clauses: The 'Eleftheria' [1970] P 94, 100. But cf Pan Australia Shipping Pty Ltd v The Ship 'Comandate' (No 2) [2006] FCA 1112, in which Rares J discussed in some detail the circumstances surrounding the making of the contract, and the location of the evidence (at [10]-[17], [23]-[27], [121]-[123]) (reversed on appeal, Comandate Marine Corporation v Pan Australia Shipping Pty Ltd (2006) 157 FCR 45).

24 For example, it was argued in one case that by failing to correspond further about a proposed reference to arbitration for four months, one party had by its conduct waived or abandoned its rights to arbitrate. This argument was rejected: Stericorp Ltd v Stericycle Inc [2005] VSC 203, [18].

25 Australian Granites Ltd v Eisenwerk Hensel Bayreuth GmbH [2001] 1 Qd R 461, 467; ACD Tridon Inc $v$ Tridon Australia Pty Ltd [2002] NSWSC 896, [53].

26 ACD Tridon Inc v Tridon Australia Pty Ltd [2002] NSWSC 896, [83] per Austin J.
} 
to arbitration" ${ }^{27}$ (waiver in the "weaker sense"). ${ }^{28}$ These requirements set a high standard and in most cases, waiver is found not to be established. ${ }^{29}$ In Comandate Marine Corporation v Pan Australia Shipping, the Full Court of the Federal Court held that the rights to arbitrate and litigate were not mutually inconsistent. ${ }^{30}$ Therefore, participation in litigation did not necessarily mean that the right to a stay had been waived.

\section{(ii) Capable of settlement by arbitration}

The parties in international commercial litigation often raise non-contractual claims, in addition to or instead of contractual claims. These include statutory, ${ }^{31}$ tortious, equitable and restitutionary claims. The plaintiff may argue that non-contractual claims are not "capable of settlement by arbitration", either because those claims do not fall within the scope of the arbitration agreement as a matter of interpretation; or because the arbitrator cannot or will not deal with those claims.

The scope of the clause is a question of interpretation. Most judges state that the specific clause is to be interpreted applying the usual principles of contractual interpretation. $^{32}$ However, the courts commence the task of interpretation using assumptions as to the scope of the agreement to arbitrate. ${ }^{33}$ The Australian cases divide

\footnotetext{
27 ACD Tridon Inc v Tridon Australia Pty Ltd [2002] NSWSC 896, [86].

28 Austin J's analysis was approved and applied by the Victorian Court of Appeal in Zhang v Shanghai Wool and Jute Textile Co Ltd (2006) 201 FLR 178, [13]-[15].

29 Cases in which waiver was not established include Comandate Marine Corporation v Pan Australia Shipping Pty Ltd (2006) 157 FCR 45, [131] per Allsop J; Zhang v Shanghai Wool and Jute Textile Co Ltd (2006) 201 FLR 178, [16]-[20]; ACD Tridon Inc v Tridon Australia Pty Ltd [2002] NSWSC 896, [79]. Cases in which waiver was established include La Donna Pty Ltd v Wolford AG (2005) 194 FLR 26, [26]; Pan Australia Shipping Pty Ltd v The Ship 'Comandate' (No 2) [2006] FCA 1112, [43], [45], 61], [69] (reversed on appeal Comandate Marine Corporation v Pan Australia Shipping Pty Ltd (2006) 157 FCR 45). See also BHPB Freight Pty Ltd v Cosco Oceania Chartering Pty Ltd (2008) 247 ALR 369, [53]-[54].

$30 \quad$ Comandate Marine Corporation v Pan Australia Shipping Pty Ltd (2006) 157 FCR 45, [62] per Allsop J (with whom Finkelstein J agreed, at [9]). Finn J agreed with Allsop J's reasoning on this point, at [3].

31 In Australia, the most common statutory claims are those arising under the Australian Trade Practices Act, especially for breach of section 52 (which prohibits a corporation, in trade or commerce, engaging in conduct which is misleading or deceptive). Other statutes which have been relied on include the Corporations Act 2001 (Cth) and the Australian Securities and Investments Commission Act 2001 (Cth).

32 ACD Tridon Inc v Tridon Australia Pty Ltd [2002] NSWSC 896, [119].

33 Fiona Trust \& Holding Corporation v Privalov [2007] UKHL 40, [13].
} 
into two categories. ${ }^{34}$ In the first category, the courts apply a relatively narrow approach to interpretation, and closely interpret the words of the agreement. ${ }^{35}$ In such a case, depending on the words of the agreement, the arbitration clause may be held not to apply to non-contractual claims, such as claims that the contract was performed negligently, that one party had made an actionable misrepresentation, or that one party had breached Australian legislation. ${ }^{36}$ Few recent cases explicitly take a narrow approach to interpretation.

In the second category, the courts apply a broad and liberal approach to interpretation of the scope of the arbitration clause. ${ }^{37}$ Allsop J stated that "the clear tide of judicial opinion as to arbitration clauses, where the fair reading of them is not confined, is to give width, flexibility and amplitude to them."38 Austin J suggested that "while Australian courts are not constrained by considerations of public policy to adopt a 'liberal' construction of arbitration clauses, reflection on the likely intention of the parties will steer them away from any narrow construction." 39 The justifications given for a broad approach to interpretation are the parties' presumed intentions, ${ }^{40}$ particularly their presumed intention not to participate in multiple proceedings for reasons of efficiency

\footnotetext{
$34 \quad$ See similarly Briggs, supra n 2, 129.

35 ACD Tridon Inc v Tridon Australia [2002] NSWSC 896, [121]; HIH Casualty \& General Insurance Ltd (in liq) $v$ RJ Wallace (2006) 68 NSWLR 603, [84] per Einstein J.

36 ACD Tridon Inc v Tridon Australia [2002] NSWSC 896, [123], [136].

37 Walter Rau Neusser Oel und Fett AG v Cross Pacific Trading Ltd [2005] FCA 1102, [41]; Seeley International Pty Ltd v Electra Air Conditioning BV (2008) 246 ALR 589, [24], [36]-[37]; Stericorp Ltd v Stericycle Inc [2005] VSC 203, [21].

38 Incitec Ltd v Alkimos Shipping Corporation (2004) 138 FCR 496, [36], cited with approval in Ansett Australia Ltd (subject to a deed of co-arrangement) and Malaysian Airline System Berhad (2008) 217 FLR 376, [13] and in Transfield Philippines Inc v Pacific Hydro Ltd [2006] VSC 175, [61] per Hollingworth J.

39 ACD Tridon Inc v Tridon Australia Pty Ltd [2002] NSWSC 896, [120], approved by the Western Australian Court of Appeal, in Paharpur Cooling Towers Ltd v Paramount (WA) Ltd [2008] WASCA 110, [34] per Steytler P and Newnes AJA.

$40 \quad$ Francis Travel Marketing Pty Ltd v Virgin Atlantic Airways Ltd (1996) 39 NSWLR 160, 165 per Gleeson CJ (Meagher and Sheller JJA agreeing, at 168); Ansett Australia Ltd (subject to a deed of co-arrangement) and Malaysian Airline System Berhad (2008) 217 FLR 376, [13] per Hollingworth J; Transfield Philippines Inc v Pacific Hydro Ltd [2006] VSC 175, [61]. See similarly Fiona Trust \& Holding Corporation v Privalov [2007] UKHL 40, [13] per Lord Hoffman.
} 
and finality ${ }^{41}$ respect for autonomy; ${ }^{42}$ conformity with commercial and common sense $;{ }^{43}$ and the desirability of the courts taking a "benevolent and encouraging approach to consensual alternative non-curial dispute resolution". ${ }^{44}$

Chief Justice Gleeson, then of the NSW Supreme Court, advocated a broad approach to interpretation in Francis Travel Marketing v Virgin Atlantic Airways. His Honour stated that

When the parties to a commercial contract agree, at the time of making the contract, and before any disputes have yet arisen, to refer to arbitration any dispute or difference arising out of the agreement, their agreement should not be construed narrowly. They are unlikely to have intended that different disputes should be resolved before different tribunals, or that the appropriate tribunal should be determined by fine shades of difference in the legal character of individual issues, or by the ingenuity of lawyers in developing points of argument. ${ }^{45}$

This statement is frequently cited, ${ }^{46}$ and has clearly influenced the modern Australian law. The Full Court of the Federal Court of Australia endorsed the liberal attitude to interpretation of arbitration agreements in Comandate Marine v Pan Australia Shipping, ${ }^{47}$ and a liberal interpretation has been applied in most cases decided since Comandate. However,

41 Walter Rau Nessau Oel Und Fett EG v Cross Pacific Trading Ltd [2005] FCA 1102, [42], [53] per Allsop J; Comandate Marine Corporation v Pan Australia Shipping Pty Ltd (2006) 157 FCR 45, [165]. See similarly Fiona Trust \& Holding Corporation v Privalov [2007] UKHL 40, [27], [28] per Lord Hope.

42 Comandate Marine Corporation v Pan Australia Shipping Pty Ltd (2006) 157 FCR 45, [165], [192].

43 Seeley International Pty Ltd v Electra Air Conditioning BV (2008) 246 ALR 589, [24]; Comandate Marine Corporation v Pan Australia Shipping Pty Ltd (2006) 157 FCR 45, [165]. See also Administration of Norfolk Island v SMEC Australia Pty Ltd [2004] NFSC 1, [132] and [139] per Beaumont J (referring to the need to be "commercially realistic" about the relationship of claims in tort (for misleading and deceptive conduct and negligence) to the overall contractual relationship between the parties).

${ }_{44}$ Walter Rau Nessau Oel Und Fett AG v Cross Pacific Trading Ltd [2005] FCA 1102, [42] per Allsop J; his Honour used the same phrase in Comandate Marine Corporation v Pan Australia Shipping Pty Ltd (2006) 157 FCR 45, [165].

$45 \quad$ Francis Travel Marketing Pty Ltd v Virgin Atlantic Airways Ltd (1996) 39 NSWLR 160, 165 (Meagher and Sheller JJA agreeing, at 168).

46 ACD Tridon Inc v Tridon Australia [2002] NSWSC 896, [120]; Comandate Marine Corporation v Pan Australia Shipping Pty Ltd (2006) 157 FCR 45, [167]; Pabarpur Cooling Towers Ltd v Paramount (W A) Ltd [2008] WASCA 110, [39]; Westrac Pty Ltd v Eastcoast Otr Tyres Pty Ltd [2008] NSWSC 894, [22].

47 (2006) 157 FCR 45, [164]-[165], [192]-[193] per Allsop J. 
in a recent case, Mansfield $\mathrm{J}$ accepted the importance of taking a broad approach to interpretation, but held that in the circumstances,

"the syntactical and semantic analysis of [the dispute resolution provision] should not be ignored because it suggests a preserved alternative but limited dispute resolution process by court proceedings. The availability of such access to the courts would not defeat the commercial purpose of the agreement; indeed it may serve it". 48

The Full Court of the Federal Court recently affirmed this decision, accepting that "in the construction of an arbitration clause the commencing point is that the parties would have intended that all disputes arising out of the contractual relationship would be decided by the same tribunal", but holding that in the circumstances that presumption was rebutted. ${ }^{49}$ The Australian courts have not gone as far as the House of Lords in explicitly adopting a presumption in favour of arbitration. ${ }^{50}$ There is neither a presumption in favour of, nor against, arbitration, in Australian law. ${ }^{51}$

It is now well-established that the parties can refer claims under Australian legislation, including the Trade Practices Act, to arbitration; ${ }^{52}$ whether they have done so is a question of the interpretation of the arbitration clause. In many cases the Australian courts have held that claims under the Trade Practices Act fall within the ambit of particular arbitration agreements. ${ }^{53}$ Similarly, in ACD Tridon v Tridon Australia, Austin J

\footnotetext{
48 Seeley International Pty Ltd v Electra Air Conditioning BV (2008) 246 ALR 589, [37].

Electra Air Conditioning BV v Seeley International Pty Ltd [2008] FCAFC 169, [40]-[41].

Fiona Trust \& Holding Corporation v Privalov [2007] UKHL 40.

ACD Tridon Inc v Tridon Australia [2002] NSWSC 896, [123], [135]-[136] per Austin J; Walter Rau Neusser Oel und Fett AG v Cross Pacific Trading Ltd [2005] FCA 1102, [41] per Allsop J.

52 Francis Travel Marketing Pty Ltd v Virgin Atlantic Airways Ltd (1996) 39 NSWLR 160, 166-167; Comandate Marine Corporation v Pan Australia Shipping Pty Ltd (2006) 157 FCR 45, [7].

$53 \quad$ Francis Travel Marketing Pty Ltd v Virgin Atlantic Airways Ltd (1996) 39 NSWLR 160, 166 per Gleeson CJ (Meagher and Sheller JJA agreeing, at 168); Comandate Marine Corporation v Pan Australia Shipping Pty Ltd (2006) 157 FCR 45, [7] per Finn J; Seeley International Pty Ltd v Electra Air Conditioning BV (2008) 246 ALR 589, [21]; Westrac Pty Ltd v Eastcoast Otr Tyres Pty Ltd [2008] NSWSC 894, [24]; Stericorp Ltd v Stericycle Inc [2005] VSC 203, [22].
} 
held that most matters under the Australian Corporations Act could be referred to arbitration, if the clause was worded appropriately. ${ }^{54}$

In several cases, judges have referred to concerns about whether arbitrators or foreign courts are able to, or are likely to, apply provisions of Australian legislation. In some of those cases, the courts have refused to stay proceedings because of this concern. ${ }^{55}$ The provision which has attracted most attention in this context is section 52 of the Trade Practices Act, which prohibits corporations, in trade or commerce, from engaging in conduct that is misleading or deceptive. In some cases, the courts' perception that an arbitrator will not apply Australian legislation, particularly if the governing law is not Australian, has led the court to retain jurisdiction. ${ }^{56}$ In Comandate Shipping v Pan Australia Shipping, the party seeking the stay anticipated and attempted to meet this concern by offering to undertake to the Australian court to consent to the foreign arbitrator determining claims made under the Trade Practices Act. ${ }^{57}$ On appeal, this undertaking was given some consideration and appears to have influenced Allsop J's conclusion that it was not appropriate to impose any condition on the stay that the defendant consent to the arbitrator considering claims arising under the Trade Practices Act. ${ }^{58}$ Allsop J stated that it was not warranted to "construe s 7(2)(b) as requiring all causes of action or issues thrown up by Australian law to be dealt with by the arbitrator according to Australian law or as they would be in a suit in this Court for the 'matter' in pursuance of the agreement to be capable of settlement by arbitration." ${ }^{59}$ His Honour held that it would be antithetical to the New York Convention if Australian courts required the arbitrator

54 ACD Tridon Inc v Tridon Australia Pty Ltd [2002] NSWSC 896, [192]. Austin J accepted that the parties could not refer to arbitration the winding up of a corporation (at [193]), following $A$ Best Flooring Sanding Pty Ltd v Skyer Australia Ltd [1999] VSC 170 (at [191]).

$55 \quad$ Walter Rau Neusser Oel und Fett AG v Cross Pacific Trading Ltd [2005] FCA 1102, [73].

56 Walter Rau Neusser Oel und Fett AG v Cross Pacific Trading Ltd [2005] FCA 1102, [73].

Pan Australia Shipping Pty Ltd v The Ship 'Comandate' (No 2) [2006] FCA 1112, [117].

Comandate Marine Corporation v Pan Australia Shipping Pty Ltd (2006) 157 FCR 45, [244]. Comandate Marine Corporation v Pan Australia Shipping Pty Ltd (2006) 157 FCR 45, [236]. 
to apply Australian legislation, on the basis that the legislation would be applied in Australian litigation.

Typically, the concern about the likelihood that claims arising under Australian legislation are arbitrable arises because the governing law is foreign. Unusually, in $H I H v W$ allace, Einstein $\mathrm{J}$ focused rather on the qualifications and expertise of the arbitrators in determining the scope of the agreement. His Honour stated that the context permitted the court "to infer that the parties would not have intended a potentially difficult legal question of policy construction to be resolved by [arbitrators who were] insurance or reinsurance executives who were not bound to apply any legal standard and from whose decision no appeal would lie." 60

Where there are matters in dispute between the parties which are not subject to the arbitration agreement, in some cases the courts have not stayed proceedings; ${ }^{61}$ but in others, the courts have stayed those parts of local proceedings which are within the scope of the arbitration agreement pending the determination of the arbitration. ${ }^{62}$

\section{(iv) Mandatory forum legislation and arbitration}

In Akai v The People's Insurance Company, the High Court by majority refused to enforce an exclusive foreign jurisdiction agreement, on the basis that to do so would undermine the effect of remedial Australian legislation. ${ }^{63}$ The majority's reasoning demonstrates the significance of mandatory forum legislation. The majority held that the forum legislation was in terms applicable, and that it was the Australian courts' responsibility to ensure that

\footnotetext{
60 (2006) 68 NSWLR 603, [118], relying on the holding in Hi-Fert Pty Ltd v Kiukiang Maritime Carriers Inc (1998) 90 FCR 1, 6 (per Beaumont J), 23 (per Emmett J) that the parties would not have intended that London arbitrators should have applied provisions of the Trace Practices Act.

$61 \quad$ Walter Rau Neusser Oel und Fett AG v Cross Pacific Trading Ltd [2005] FCA 1102, [106].

62 Zhang v Shanghai Wool and Jute Textile Co Ltd (2006) 201 FLR 178, [27].

63 (1996) 188 CLR 418, 447. The provision in issue was the Insurance Contracts Act 1984 (Cth) s 54.
} 
it would be applied. ${ }^{64}$ They held that unless the defendant could show that the foreign court would apply the legislation, an Australian court must ensure the application of the legislation by retaining jurisdiction. ${ }^{65}$ In American Diagnostica Inc v Gradipore Ltd, Giles CJ stated that

"party autonomy does not mean complete freedom to exclude a system of law, or particular elements of a system of law, from the relationship between the parties. Confining attention to statutory law, if the statute on its proper construction and with regard to the legislative power of the legislature applies to the parties and their conduct of the arbitration, the agreement of the parties to exclude it will count for nothing." 66

Section 52 of the Australian Trade Practices Act is sometimes regarded as having internationally mandatory effect; that is, that it ought to be applied notwithstanding an otherwise effective choice of law. ${ }^{67}$ In some cases, Australian courts have refused to refer matters to arbitration where section 52 is invoked. ${ }^{68}$ In Pan Australia Shipping v The Ship 'Comandate' (No 2), Rares J's reasoning for retaining jurisdiction reflects similar concerns to those identified by the majority in Akai, concerning the nature of the Trade Practices Act and the courts' responsibilities in relation to enforcing the provisions of that Act. ${ }^{69}$ On appeal, this aspect of Rares J's decision was reversed. Finn J stated that

"whatever advantage or disadvantage accrued to Pan from having both the relevant legal effects of its pre-contractual conduct and its Trade Practices Act claims

\footnotetext{
64 (1996) 188 CLR 418, 444, 447.

65 (1996) 188 CLR 418, 444-445.

66 American Diagnostica Inc v Gradipore Ltd (1998) 44 NSWLR 312, 328.

67 The legislation does not specifically state that section 52 is to be given such an effect.

68 Pan Australia Shipping Pty Ltd v The Ship 'Comandate' (No 2) [2006] FCA 1112, [91] per Rares J; reversed on appeal, Comandate Marine Corp v Pan Australia Shipping Pty Ltd (2006) 157 FCR 45, [8] per Finn J, [240] per Allsop J.

69 Pan Australia Shipping Pty Ltd v The Ship 'Comandate' (No 2) [2006] FCA 1112, [91] ("Part V of the Trade Practices Act 1974 (Cth), in which s 52 is found, sets out a statutory norm of conduct to which corporations must conform in trade or commerce. The task of the Court is to apply such norms where they arise in litigation").
} 
determined in London according to English law..., this is what has been agreed to by the parties as international commercial contractors. There is no legal principle of, nor is there any policy immanent in Australian law that denies them what they have agreed." 70

In the same case Allsop J engaged in a detailed analysis of the interaction between the International Arbitration Act and the Trade Practices Act. His Honour observed that the Trade Practices Act "is a statute of the highest importance in connection with commercial activity and behaviour in Australia and in the promotion of the welfare of Australians." 71 But Allsop J went on to point out that while parliament had explicitly provided that the Australian Carriage of Goods by Sea Act was not subject to the provisions of the International Arbitration Act, ${ }^{72}$ no such exclusion had been made in relation to the Trade Practices Act, and that consequently the Trade Practices Act was subject to the International Arbitration Act. ${ }^{73}$

There are very few cases in which forum legislation has been explicitly characterised as having mandatory effect with the effect of overriding an otherwise valid arbitration agreement. In HIH Casualty \& General Insurance v Wallace, Einstein J treated section 19 of the New South Wales Insurance Act as a mandatory provision, which rendered the arbitration agreement inoperative for the purposes of subsection 7(5) of the International Arbitration Act. ${ }^{74}$ Section 19 states that

"A provision in a contract of insurance... being a provision with respect to the submission to arbitration of any matter arising out of the contract of insurance, does not bind the insured except where the provision is contained in a contract or

\footnotetext{
$70 \quad$ Comandate Marine Corporation v Pan Australia Shipping Pty Ltd (2006) 157 FCR 45, [8]. See similarly at [240] per Allsop J.

$71 \quad$ Comandate Marine Corporation v Pan Australia Shipping Pty Ltd (2006) 157 FCR 45, [195].

72 International Arbitration Act 1974 (Cth) s 2C.

73 Comandate Marine Corporation v Pan Australia Shipping Pty Ltd (2006) 157 FCR 45, [196].

74 (2006) 68 NSWLR 603, [19], [58].
} 
agreement, entered into after a difference or dispute has arisen between the insurer and the insured, providing for the submission to arbitration of that difference or dispute." 75

Einstein J characterised this legislation as "beneficial and remedial", ${ }^{76}$ and stated that this provision was a mandatory law of the forum which would operate irrespective of what was otherwise be the proper law of the contract. ${ }^{77}$ Applying section 19, Einstein J held that the arbitration agreement was inoperative. ${ }^{78}$

\section{(v) Multiplicity of proceedings}

The International Arbitration Act specifically anticipates that some matters might be beyond the scope of the agreement. Subsection 7(2) provides that, where the matter in dispute in proceedings "is capable of settlement by arbitration... the court shall ... stay the proceedings or so much of the proceedings as involve the determination of that matter ... and refer the parties to arbitration in respect of that matter." 79 Most recent cases attempt to avoid a multiplicity of litigation, and this polarises results. The most likely consequence in recent Australian litigation is that the court commences the interpretation process with a strong inclination to avoid duplication, in which case their interpretation inevitably concludes that the clause encompasses all matters in dispute. For example, Hollingworth J stated that "[a]s far as reasonably possible, the arbitration agreements should be given a construction which avoids the inconvenience of a divided dispute and multiplicity of proceedings." 80 In a small number of cases, Australian courts have retained jurisdiction

\footnotetext{
75 Insurance Act 1902 (NSW) s 19. See similarly Insurance Contracts Act 1984 (Cth) s 43.

(2006) 68 NSWLR 603, [28]. [36], [111].

(2006) 68 NSWLR 603, [35]. His Honour found, in any event, that NSW law was the proper law:

(2006) 68 NSWLR 603

International Arbitration Act 1974 (Cth) s 7(2) (emphasis added).

Transfield Philippines Inc v Pacific Hydro Ltd [2006] VSC 175, [61], citing IBM Australia Ltd v National Distribution Services Ltd (1991) 22 NSWLR 466, 472-473. See also Comandate Marine Corporation v Pan Australia Shipping Pty Ltd (2006) 157 FCR 45, [170].
} 
to avoid the risk of inconsistent findings where the dispute involved claims which were not subject to the arbitration agreement. ${ }^{81}$

\section{(vi) Multiple parties}

While the International Arbitration Act anticipates the possibility that disputes may include matters that are subject to arbitration, as well as matters that are not subject to arbitration, it makes no allowance for the existence of third parties to the arbitration agreement. In some cases, the Australian courts have held that if there are third parties involved in the dispute who are not bound by the agreement, in order to ensure a complete resolution of the dispute, a stay should not be granted. ${ }^{82}$ The justifications for narrowly interpreting the scope of the arbitration agreement in cases where third parties are involved in the dispute, with the result that the agreement may be interpreted not to apply to third party disputes, are similar to those for enforcement of arbitration agreements referred to above; namely, giving effect to the parties' presumed intentions, efficiency, and avoiding potentially inconsistent outcomes. ${ }^{83}$

In Paharpur Cooling Towers v Paramount (WA), Steytler P and Newnes JA suggested that

"where a party to an arbitration agreement makes the same claim both against the other party to the arbitration agreement and a person who is not a party to the arbitration agreement - with the result that, so far as it involves the latter, the dispute cannot be referred to arbitration - it will generally be equally difficult to ascribe to the parties to the arbitration agreement an intention that in such an event the dispute should be fragmented and that the liability of the party to the arbitration

\footnotetext{
81 Walter Rau Neusser Oel und Fett AG v Cross Pacific Trading Ltd [2005] FCA 1102, [110].

$82 W$ Walter Rau Neusser Oel und Fett AG v Cross Pacific Trading Ltd [2005] FCA 1102, [77], [78], [80], [105] (particularly because fraud had been alleged, and it was in the public interest to deal expeditiously with a case involving such serious allegations).

83 Paharpur Cooling Towers Ltd v Paramount (WA) Ltd [2008] WASCA 110, [43]-[44].
} 
agreement and that of the third party respectively should be determined in different

forums." 84

In Origin Energy Resources v Benaris International, Slicer J held that matters that may have been arbitrable as between the parties to the arbitration agreement were not arbitrable because any resultant award would, once enforced in the forum, have effect against a third party, which would not have participated in the arbitration. Slicer J held that this might amount to a denial of natural justice as against the third party. ${ }^{85}$

In other cases, the Australian courts have emphasised the mandatory terms of subsection 7(2) and have stayed related local proceedings in favour of arbitration, even though those proceedings involve third parties to the arbitration agreement, and matters which are not subject to arbitration. ${ }^{86}$

The courts only rarely explicitly consider whether the involvement of multiple parties, or the inclusion of non-contractual claims, appears authentic or whether those parties or claims appear to be included for "the improper purpose of fabricating jurisdiction", 87 in order to avoid the effect of the arbitration agreement. ${ }^{88}$

\section{(vii) Matters which render the agreement null and void}

There are very few Australian cases in which the plaintiff has argued that the agreement is null and void. In Hi-Fert v Kinkiang Maritime Carriers, Emmett J held that if enforcing an arbitration agreement would result in one party being deprived of the ability to claim

\footnotetext{
$84 \quad$ Paharpur Cooling Towers Ltd v Paramount (WA) Ltd [2008] WASCA 110, [43].

85 Origin Energy Resources Ltd v Benaris International NV (No 2) [2002] TASSC 104, [37], [39], [41].

86 Origin Energy Resources Ltd v Benaris International NV [2002] TASSC 50. Slicer J placed significant weight on the mandatory nature of $\mathrm{s} 7(2)$, but also seems to have placed weight on his perception that resolution of issues under the contract which was amenable to arbitration were preliminary to resolving other issues between the arbitrating parties, and issues involving the third party (at [30], [34], cf [52]). See also Origin Energy Resources Ltd v Benaris International NV (No 2) [2002] TASSC 104. Similarly in Stericorp Ltd $v$ Stericycle Inc [2005] VSC 203, there was one matter in dispute which the parties agreed was not subject to arbitration. Whelan J granted a stay in any event and stated that "I will grant leave to amend and will consider what claims if any can proceed before the arbitration is concluded" (at [26]).

87 Pan Australia Shipping Pty Ltd v The Ship 'Comandate' (No 2) [2006] FCA 1112, [90] per Rares J.

$88 \quad$ Eg Mulgrave Central Mill Co Ltd v Hagglund Drives Ltd [2002] 2 Qd R 514, [24]
} 
under the Trade Practices Act, this might mean that the arbitration agreement was void. ${ }^{89}$ The doctrine of separability is now fairly well-established in Australia, ${ }^{90}$ so a general attack on the validity of a contract does not render an arbitration agreement null and void.

\section{(viii) Exclusivity?}

In some cases, arbitration agreements occur in the same contract as jurisdiction clauses or service of suit clauses. ${ }^{91}$ Typically, one party to the contract is given an election whether to litigate or arbitrate; ${ }^{92}$ sometimes, specific types of dispute resolution are available depending on the kind of dispute. These arbitration agreements are therefore not "exclusive", by analogy to the distinction between exclusive and non-exclusive jurisdiction clauses. The number of cases is small, but where the arbitration agreement is not exclusive in this sense, the Australian courts tend not strictly to enforce the agreement to arbitrate. For example, in Paharpur Cooling Towers Ltd v Paramount (W A) Ltd, the contract gave the defendant the option of arbitration or litigation. ${ }^{93}$ The Western Australian Court of Appeal did not rely specifically on this factor but refused to order a stay. $^{94}$

\section{(ix) Divergence in outcomes}

Even in cases in which the courts ostensibly strictly enforce the arbitration agreement, they commonly impose conditions, such as obliging the successful party "to act promptly

\footnotetext{
$89 \quad$ Hi-Fert Pty Ltd v Kiukiang Maritime Carriers Inc (1996) 71 FCR 172, 24.

$90 \quad$ Comandate Marine Corporation v Pan Australia Shipping Pty Ltd (2006) 157 FCR 45, [228]; Walter Rau Neusser Oel und Fett AG v Cross Pacific Trading Ltd [2005] FCA 1102, [89]; Ferris v Plaister (1994) 34 NSWLR 474, 504;

91 HIH Casualty \& General Insurance Ltd (in liq) v RJ Wallace (2006) 68 NSWLR 603, [15]. See similarly Seeley International Pty Ltd v Electra Air Conditioning BV (2008) 246 ALR 589.

92 HIH Casualty \& General Insurance Ltd (in liq) v RJ Wallace (2006) 68 NSWLR 603, [15], [98]. 93 [2008] WASCA 110, [5]

94 The principal justification for retaining jurisdiction was that the case involved multiple parties who were not parties to the arbitration agreement: Pabarpur Cooling Towers Ltd v Paramount (W A) Ltd [2008] WASCA 110, [43].
} 
to enable the arbitration to commence and proceed with due expedition", ${ }^{95}$ or to undertake to consent to the submission of claims arising under Australian legislation to arbitration. ${ }^{96}$ The cases produce inconsistent outcomes when some elements of the overall dispute do not come within the terms of the arbitration. In some cases, a stay of litigation is granted until the arbitration is concluded; ${ }^{97}$ in others, stays are granted but only of parts of the dispute, and litigation in respect of the other matters is permitted to proceed first; ${ }^{98}$ and in others, quite different relief is ordered. Austin J applied an inventive solution in ACD Tridon $v$ Tridon Australia. Austin $\mathrm{J}$ held that only some of the matters in dispute came within the scope of the two arbitration agreements. ${ }^{99} \mathrm{He}$ observed that it would be unsatisfactory, costly and wasteful if the parties were to proceed with both the litigation and arbitration. Consequently, he referred all the plaintiff's claims to the arbitrator who had already been nominated by the parties, as a referee under the NSW rules of court. ${ }^{100}$

$95 \quad$ Ansett Australia Ltd (subject to a deed of co-arrangement) and Malaysian Airline System Berbad (2008) 217 FLR 376, [38]. See similarly Origin Energy Resources Ltd v Benaris International NV [2002] TASSC 50, [54] per Slicer J; Administration of Norfolk Island v SMEC Australia Pty Ltd [2004] NFSC 1, [118] per Beaumont J; and Australian Power and Water Pty Ltd v Independent Public Business Corporation of Papua New Guinea [2003] NSWSC 1227, [80] (foreign mediation agreement). In Ansett Australia Ltd (subject to a deed of co-arrangement) and Malaysian Airline System Berbad, Hollingworth J also imposed a condition that the successful party not be entitled to rely on any limitation period issue which was not available to it at the time that the unsuccessful party commenced litigation (at (2008) 217 FLR 376, [33]); this condition was imposed because of the successful party's delaying conduct in litigation.

$96 \quad$ In Walter Rau Neusser Oel und Fett AG v Cross Pacific Trading Ltd [2005] FCA 1102, [111] Allsop J imposed a condition that the parties to the arbitration "consent to all aspects of the TP Act claims, which would have been justiciable in this Court, being litigated in the arbitration irrespective of any conclusion as to the proper law." Somewhat optimistically, he suggested that this condition "would solve the potential conflict of Australian domestic statutory public policy and the operation by a foreign arbitrator of the rules of conflicts of law to set at nought governing Australian law. The arbitration agreement is a contract about submission. Its enforcement should not undermine the operation of a statute such as the TP Act." See also Reinsurance Australia Corp v Members of Lloyd's Syndicate 1027 [2001] FCA 1426, [12].

$97 \quad$ Origin Energy Resources Ltd v Benaris International NV [2002] TASSC 50.

98 Hi-Fert Pty Ltd v Kiukiang Maritime Carriers Inc (1996) 71 FCR 172; Incitec Ltd v Alkimos Shipping Corporation (2004) 138 FCR 496; Westrac Pty Ltd v Eastcoast Otr Tyres Pty Ltd [2008] NSWSC 894, [42].

99 ACD Tridon Inc v Tridon Australia Pty Ltd [2002] NSWSC 896, [177]. The arbitration agreements were also of limited efficacy in that not all parties to the litigation were parties to both arbitration agreements: at [28].

100 Under Part 72 of the now repealed Supreme Court Rules 1970 (NSW). Although an unusual solution, it was not novel: see Aerospatiale Holdings Australia v Elspan International Ltd (1992) 28 NSWLR 321. Cf Westrac Pty Ltd v Eastcoast Otr Tyres Pty Ltd [2008] NSWSC 894, [32], [40]. 
In order to assess the effectiveness of the International Arbitration Act, it is illuminating to consider the manner in which the Australian superior courts have dealt with applications for a stay of Australian proceedings, in favour of arbitration agreements. Accordingly, as part of this study, I conducted a quantitative analysis of all decisions of Australian superior courts between 2001 and 2008 in which the court decided whether to stay proceedings. In the period 2001-2008, ${ }^{101}$ there was more litigation in the Australian superior courts concerning the enforcement of international arbitration agreements than there was concerning the enforcement of foreign jurisdiction agreements. ${ }^{102}$ Of the 17 cases identified in which the courts substantively addressed the question whether to stay local proceedings in favour of an arbitration agreement, a stay was granted in 10 cases. Of those 10 cases, the stay was granted without conditions in only four cases. ${ }^{103}$ In 12 of the 17 cases, the plaintiff was Australian, whereas only 6 of 17 first defendants were Australian. In eight cases, there were other parties to the dispute, and in 12 cases, the dispute involved non-contractual claims. ${ }^{104}$

\footnotetext{
101 The empirical study reported here (in respect of arbitration agreements) and below, at Section C2(c) (in respect of choice of court agreements), is in part an extension of the study of the outcome of jurisdictional disputes by Keyes, in which she analysed international jurisdictional disputes decided in the Australian superior courts between 1991 and 2001: Jurisdiction in International Litigation (2005, Federation Press, Sydney), 149-175.

102 On LexisNexis' Casebase, Thomson's FirstPoint and AustLII databases, using the search terms "international arbitration act and stay" and "arbitration agreement and stay", 25 cases were identified, of which eight were excluded for various reasons, as for example where injunctions were sought restraining foreign proceedings being continued in breach of arbitration agreements, or where the court determined the dispute on another basis (eg Transfield Philippines Inc v Pacific Hydro Ltd [2006] VSC 175, holding that service should be set aside because the writ was incorrectly indorsed). After excluding the cases in which the court did not decide whether to stay proceedings or not, there were 17 separate cases in which the court determined whether a stay should be granted. This included three cases which were appeals from primary decisions which are also included in the sample, in which the appeal court fully considered whether a stay should be granted. The reason for retaining the primary decision in the sample, even where that decision was appealed, was to examine the factors which influence judicial decision making in relation to the exercise of jurisdiction, which is the focus of this study (rather than the ultimate determination of any matter).

103 In one of those four cases, conditions were not imposed apparently only because of the undertaking offered by the defendant to submit disputes arising under Australian legislation to arbitration.

104 In seven cases, relief was sought under the Trade Practices Act (or the State Fair Trading Act equivalent). In two cases the Corporations Act 2001 (Cth) was invoked, and in one case the Insurance
} 
Although the number of cases is small, some interesting trends emerged from the data.

First, the Australian courts are in general not parochial in determining whether to stay proceedings in favour of arbitration agreements. They displayed no preference for local plaintiffs over foreign plaintiffs; ${ }^{105}$ no preference where the governing law was local; ${ }^{106}$ and no preference where the place of arbitration was within Australia. ${ }^{107}$ Local defendants did, however, fare better than foreign defendants. ${ }^{108}$ Second, where the court explicitly adopted a liberal approach to interpretation of the arbitration clause, the court was predictably twice as likely to stay proceedings as in cases where the judge explicitly took a literal approach to interpretation. ${ }^{109}$ Third, where there were third parties involved, the court was more likely to stay proceedings than in cases where there were no third parties. ${ }^{110}$ This result is counter-intuitive; it suggests that the addition of third parties is ineffective as a strategy for avoiding arbitration agreements in Australia. Fourth, where the litigation involved matters other than the contractual and related matters that were arbitrable, the court was much less likely to grant a stay. ${ }^{111}$ Fifthly, the

Contracts Act 1902 (NSW) was invoked. In two cases, disputes concerning other contracts were raised; in two cases, equitable relief was sought; in two cases, common law misrepresentation was claimed; and in one case each, there were claims of fraud, negligence and in restitution

105 Stays were granted in $58 \%$ of cases involving local plaintiffs ( 7 of 12 cases), and in $60 \%$ of cases involving foreign defendants ( 3 of 5 cases).

106 Stays were granted in $50 \%$ of cases where the governing law was local ( 2 of 4 cases), and in $50 \%$ of cases where the governing law was foreign ( 2 of 4 cases). The governing law was not identified in the judgment in nine cases; of those cases, stays were granted in $67 \%$ of cases (6 of 9 ).

107 Stays were granted in $50 \%$ of cases where the place of arbitration was within Australia (4 of 8 cases), and in $50 \%$ of cases where the place of arbitration was not within Australia (3 of 6 cases). The place of arbitration was not identified in 3 cases, and a stay was granted in all of those cases.

108 Stays were granted in $67 \%$ of cases involving local defendants (4 out of 6 cases), but in only $55 \%$ of cases involving foreign defendants (6 out of 11 cases).

109 Stays were granted in $64 \%$ of cases in which a wide interpretation was expressly endorsed $(7$ of 11 cases), but in only $33 \%$ of cases in which a literal interpretation was applied (1 of 3 cases). There were three cases in which neither approach was referred to, in which stays were granted in $67 \%$ of cases (1 of 3 cases).

110 Stays were granted in $75 \%$ of cases where there were third parties involved in the local litigation ( 6 of 8 cases), but in only $44 \%$ of cases in which there were no third parties (4 of 9 cases).

111 Stays were granted in 50\% of cases in which the litigation involved non-arbitrable matters (7 of 14 cases), and in $100 \%$ of cases which did not involve other matters (3 of 3 cases). 
Australian courts are less likely to stay proceedings in matters involving claims under Australian legislation. ${ }^{112}$.

Most of these results are predictable, and suggest that the International Arbitration Act is largely effective. However, the analysis shows that there is still scope for avoiding an arbitration agreement in Australian litigation, by the inclusion of statutory and other noncontractual claims.

\section{(c) Conclusion}

Although the International Arbitration Act is in general being applied correctly, there remains some inconsistency in results. In interpreting the scope of arbitration agreements, some Australian courts emphasised that the parties are unlikely to have intended that dispute resolution should be fragmented and have therefore read down the scope of the arbitration agreement. Other commentators have noted that the Australian courts have not fully given effect to international arbitration agreements, ${ }^{113}$ and King has suggested that consequently that the New York Convention should be reviewed, in the light of developing concerns about fragmentation of disputes. ${ }^{114}$ The Commonwealth Attorney General commenced a process of reviewing the Act in November $2008 .^{115}$

\footnotetext{
112 Stays were granted in 50\% of cases involving claims under Australian legislation (5 of 10 cases), and in $71 \%$ of cases not involving claims under Australian legislation (5 of 7 cases).

$113 \mathrm{~J}$ Delaney and K Lewis, "The Presumptive Approach to the Construction of Arbitration Agreements and the Principle of Separability - English Law Post Fiona Trust and Australian Law Contrasted" (2008) 31 University of New South Wales Law Journal 341, 350; R Garnett, "The Current Status of International Arbitration Agreements in Australia" (1999) 15 Journal of Contract Law 29.

114 PE King, "Contemporary Developments in the Law of International Arbitration in Australia and New Zealand” (1999) 18 Australian Bar Review 254, 256.

115 At the time of writing, the review was in progress. See Commonwealth Attorney General's Department, Review of the International Arbitration Act 1974: Discussion Paper (Canberra, Commonwealth of Australia, 2008, available at http://www.ag.gov.au/www/agd/rwpattach.nsf/VAP/(3A6790B96C927794AF1031D9395C5C20) Revi $\underline{\text { ew }+ \text { of }+ \text { the }+ \text { International }+ \text { Arbitration }+ \text { Act }+1974+-}$ +Discussion+Paper.DOC/\$file/Review + of +the+International+Arbitration+Act+1974++ Discussion+Paper.DOC last accessed 29 April 2009).
} 


\section{International Jurisdictional Agreements in Australian Litigation}

The treatment of jurisdictional agreements by the Australian courts differs markedly from that of arbitration agreements. The principles applied to exclusive foreign jurisdiction agreements are distinct from those applicable to arbitration agreements and to cases where there is no effective choice of courts agreement. Derogation clauses are treated differently to prorogation clauses; the principles relevant to each are described below.

\section{(a) Prorogation Clauses}

Contractual submissions to the jurisdiction of local courts are a basis of in personam jurisdiction at common law, and under rules of court. ${ }^{116}$ There are no specific principles in Australia that apply when one party argues that local proceedings should be stayed where there is an effective choice of Australian courts clause. In the few cases in which prorogation clauses have been challenged, the courts have applied the Australian principle of forum non conveniens to determine whether they should be enforced, ${ }^{117}$ rather than analogising prorogation clauses to derogation clauses. As a matter of principle, prorogation clauses should be dealt with in the same way as derogation agreements. ${ }^{118}$

In Armacel v Smurfit Stone Container, ${ }^{119}$ the parties had contractually submitted "to the jurisdiction of' NSW. The defendant to proceedings in the Australian Federal Court commenced proceedings for negative declaratory relief in the US District Court one

\footnotetext{
116 Eg Federal Court Rules 1979 (Cth) O 8 r 2 item 17; Uniform Civil Procedure Rules 2005 (NSW) r 11.2, Sch 6 para (h); Supreme Court (General Civil Procedure) Rules 2005 (Vic) r 7.01(1)(h).

117 HIH Casualty \& General Insurance Ltd v Meadows Indemnity Co Ltd (1998) 47 NSWLR 85, 101; Kirby $v$ International Cargo Control Pty Ltd [2000] NSWSC 289, [24]; Cigna Insurance Australia Ltd v CSR Ltd (unreported, NSWSC, 20 February 1996).

118 Keyes, supra n 101, 100-101. In Donobue v Armco Inc, the House of Lords applied the same principle which is applied to determine whether choice of foreign courts clauses should be enforced, to determine whether a choice of English courts clause should be enforced: [2002] 1 All ER 749, 759.

119 Armacel Pty Ltd v Smurfit Stone Container Corporation (2008) 248 ALR 573.
} 
month before Australian proceedings were commenced. The US District Court held that the jurisdiction agreement was a non-exclusive jurisdiction clause. ${ }^{120}$ Jacobson J held that this created an issue estoppel which prevented the applicant in Australian proceedings from contending that the agreement was exclusive, ${ }^{121}$ even though his Honour noted that under Australian law the clause would have been regarded as an exclusive submission to jurisdiction. ${ }^{122}$

\section{(b) Derogation Clauses}

The Australian principle is that derogation clauses should be enforced in the absence of strong grounds for non-enforcement. ${ }^{123}$ While this principle appears to give priority to enforcing agreements, strong grounds are relatively easily established. Strong grounds for non-enforcement can be shown in two situations. The first, more common, situation is where local "remedial" legislation is invoked, and the court accepts that granting a stay would deprive the plaintiff of their ability to claim relief under that legislation. ${ }^{124}$ The second is the existence of third parties who are not bound by the jurisdiction agreement. $^{125}$

Several courts have held that a choice of courts agreement may not be upheld where enforcing the agreement would mean that Australian remedial legislation, such as the

\footnotetext{
120 Armacel Pty Ltd v Smurfit Stone Container Corporation (2008) 248 ALR 573, [6].

121 Armacel Pty Ltd v Smurfit Stone Container Corporation (2008) 248 ALR 573, [66]. This decision is questionable; the US court's decision should only be recognised by an Australian court if the US court is regarded as having international jurisdiction (The 'Sennar' [1985] 2 All ER 104, 106 per Lord Diplock, 110 per Lord Brandon). That would require the defendant to foreign proceedings either to have submitted to the foreign jurisdiction, or to have been served with commencing process while present in the foreign jurisdiction. Neither seems likely. Merely appearing in foreign proceedings for the purposes of contesting the foreign court's jurisdiction does not constitute a submission to the jurisdiction of the foreign court (Foreign Judgments Act 1991 (Cth) s 11 (d) and (e)). Jacobson J's judgment contains no reference to the requirement that the foreign court be regarded as jurisdictionally competent.

122 Armacel Pty Ltd v Smurfit Stone Container Corporation (2008) 248 ALR 573, [90].

123 Akai Pty Ltd v The People's Insurance Co Ltd (1996) 188 CLR 418, 445, 447; Incitec Ltd v Alkimos Shipping Corporation (2004) 138 FCR 496, [42].

124 Reinsurance Australia Corp v HIH Casualty and General Insurance (in liq) [2003] FCA 56, [349]; Commonwealth Bank of Australia v White [1999] 2 VR 681. See similarly Quinlan v SAFE International Försäkrings $A B$ (2006) 14 ANZ Ins Cas 61-693, [49], [50] per Nicholson J (a case excluded from this analysis, because it involved a consumer).

125 Incitec Ltdv Alkimos Shipping Corporation (2004) 138 FCR 496.
} 
Insurance Contracts Act 1984 and the Trade Practices Act, would not be applied. ${ }^{126}$ In Clough Engineering v Oil and Natural Gas Corporation, Gilmour J stated that, "If an Australian protective provision would be avoided by forcing an applicant to sue in the courts of a nominated jurisdiction, that is an important factor which should overcome the predisposition of a court" to enforce the jurisdictional clause. ${ }^{127}$ Most commentators argue that it is generally inappropriate to allow parties to avoid their contractual bargain by claiming relief under Australian legislation, unless there are very specific circumstances. ${ }^{128}$ Prevention of the fragmentation of disputes, with the attendant inefficiencies, inconvenience, and risks of inconsistent judgments, has also emerged as a strong reason for retaining jurisdiction, assuming that the forum is competent to deal with all matters in dispute and all parties. ${ }^{129}$ The courts have referred to the tension between
"two powerful considerations in international litigation: first, the desire of courts to hold commercial parties to their bargain in terms of exclusive jurisdiction clauses; secondly, the desire of courts to avoid disruption and multiplicity of litigation, in particular a desire to avoid parallel proceedings and the risk of inconsistent findings, and to avoid the causing of inconvenience to third parties." 130

Garnett has heavily criticised this justification, stating that "allowing a plaintiff to overcome a foreign jurisdiction clause by the simple expedient of bringing proceedings

\footnotetext{
$126 \quad$ Akai Pty Ltd v The People's Insurance Co Ltd (1996) 188 CLR 418, 445; Clough Engineering Ltd v Oil and Natural Gas Corporation Ltd [2007] FCA 881, [40]-[43]; Hume Computers Pty Ltd v Exact International BV [2006] FCA 1440, [21], [22] per Jacobson J; Commonwealth Bank of Australia v White [1999] 2 VR 681, [89], [91]; The Society of Lloyd's $v$ White [2004] VSCA 101, [19]. See similarly Quinlan v SAFE International Försäkerings $A B$ (2006) 14 ANZ Ins Cas 61-693, [49], [50] per Nicholson J.

127 Clough Engineering Ltd v Oil and Natural Gas Corporation Ltd [2007] FCA 881, [43]. See similarly Commonwealth Bank of Australia v White [1999] 2 VR 681, [89].

128 R Garnett, "The Enforcement of Jurisdiction Clauses in Australia" (1998) University of New South Wales Law Journal 1, 19 (asserting that this should only be permitted if the plaintiff can show that the consequence of enforcing the jurisdiction agreement would be that they would "be denied a specific right of action" or where the consequences of the jurisdiction agreement at the time of litigation, in terms of the relief that might be awarded in the foreign court, are different to the consequences at the time the contract was made).

$129 \quad$ Incitec Ltd v Alkimos Shipping Corporation (2004) 138 FCR 496, [49], [62]-[64].

130 Incitec Ltd v Alkimos Shipping Corporation (2004) 138 FCR 496, [47].
} 
against another person in the forum" seriously undermines the weight that should be given to jurisdiction agreements. ${ }^{131}$

In determining whether the foreign jurisdiction agreement should be enforced, judges often refer to the factors identified by Brandon $\mathrm{J}$ in The 'Eleftheria'. ${ }^{132}$ These include factors of convenience and expense relating to the location of evidence; the governing law; the parties' connections to different countries; whether "the defendants genuinely desire trial in the foreign country, or are only seeking procedural advantages"; and whether the plaintiff would be prejudiced by enforcement of the agreement, for example by not being able to enforce any judgment, by a less favourable limitation period, and by facing difficulty in getting a fair trial for "political, racial, religious, or other reasons". ${ }^{133}$ These factors were influential in the development of the English principle of forum non conveniens; they closely resemble the connecting factors identified by Lord Goff as relevant to determining the natural forum. ${ }^{134}$ Therefore, the inquiry whether to retain or decline jurisdiction is very similar, whether or not there is an effective exclusive jurisdiction agreement. ${ }^{135}$ Reducing the status of an exclusive jurisdiction agreement in this way places insufficient emphasis on the importance of enforcing jurisdiction agreements, and goes some way to explaining why the success rate of defendants is worse

\footnotetext{
131 Garnett, "The Enforcement of Jurisdiction Clauses" supra n 128, 13.

132 The 'Eleftheria' [1970] P 94, 100; cited with approval in Akai Pty Ltd v The People's Insurance Company Ltd (1996) 188 CLR 418, 428, 444-445.

133 The 'Eleftheria' [1970] P 94, 100.

134 Spiliada Maritime Corporation v Cansulex [1987] AC 460, 478.

135 In Quinlan v SAFE International Försäkrings $A B$, Nicholson J noted that the same factors which justified not enforcing the jurisdiction agreement were also relevant to establishing that the forum was not clearly inappropriate: (2006) 14 ANZ Ins Cas 61-693, [53]. See also Bell, supra n 4, 322. Cf Incitec Ltd v Alkimos Shipping Corporation (2004) 138 FCR 496, [42], where Allsop J stated that "The discretion not to grant a stay [in favour of the jurisdiction agreement] requires strong grounds. It is not a matter of mere convenience or of forum non conveniens." See similarly Reinsurance Australia Corp v HIH Casualty and General Insurance (in liq) [2003] FCA 56, [342]; FAI General Insurance Co Ltd v Ocean Marine Mutual Protection and Indemnity Association (1997) 41 NSWLR 559, 569.
} 
in cases involving choice of courts agreements than in cases involving arbitration agreements. ${ }^{136}$ Bell has argued persuasively that The 'Eleftheria' should be overruled. ${ }^{137}$

In 1998, Garnett suggested that the Australian courts took a more relaxed approach to the enforcement of jurisdiction agreements than arbitration agreements, ${ }^{138}$ and an analysis of the recent cases bears this out. In many cases, the courts give insufficient priority to choice of courts clauses. For example, in Puccini Festival Australia Pty Ltd v Nippon Express (Australia) Pty Ltd, the defendant relied on an exclusive foreign jurisdiction clause contained in a bill of lading. The plaintiff disputed that it was a party to the bill of lading, and that the terms of the bill of lading formed part of the contract. ${ }^{139}$ Cavanough $\mathrm{J}$ stated that because the issue of whether the bill of lading bound the plaintiff would be a major issue at trial, it was "undesirable for me to say more about it than necessary at this interlocutory stage". ${ }^{140}$ This is unsatisfactory; the validity of the exclusive jurisdiction clause should have had a material effect on the outcome of this dispute.

\section{(i) Scope of Jurisdiction Clauses}

The principles applied in interpreting jurisdiction clauses are similar to those applied in the interpretation of arbitration clauses. ${ }^{141}$ Allsop J stated that "provisions conferring jurisdiction...should be interpreted liberally and without imposing limitations not found in the express words." ${ }^{142}$ However, as for arbitration clauses, in some cases the courts interpret jurisdiction clauses strictly. Duggan J recently stated that "The tendency to

\footnotetext{
136 Bell, supra n 4, 321.

137 Ibid, 327-328.

138 Garnett, “The Enforcement of Jurisdiction Clauses”, supra n 128, 9.

139 Puccini Festival Australia Pty Ltd v Nippon Express (Australia) Pty Ltd (2007) 17 VR 36, [26].

$140 \quad$ Puccini Festival Australia Pty Ltd v Nippon Express (Australia) Pty Ltd (2007) 17 VR 36, [29]; see also at [57] (stating that a relevant fact in deciding what weight to give jurisdiction agreement was the argument that the agreement was not binding on the plaintiff). His Honour also took the view that the Carriage of Goods by Sea Act 1991 (Cth) s 11 rendered the jurisdiction agreement in the bill of lading ineffective: [57]. Of course, s 11 applies only to contracts for the carriage of goods by sea from Australian ports: s 11(1).

141 Incitec Ltd v Alkimos Shipping Corporation (2004) 138 FCR 496, [36]. Vetreria Etrusca Srl v Kingston Estate Wines Pty Ltd [2008] SASC 75, [16] per Duggan J, citing Comandate Marine Corporation v Pan Australia Shipping Pty Ltd [2006] FCAFC 192, [162].

142 Heilbrunn v Lightwood Plc (2007) 243 ALR 343, [29].
} 
adopt a liberal approach to the interpretation of an exclusive jurisdiction or arbitration clause which is couched in general words does not apply with equal force in a case such as the present where specific areas of dispute are identified in the jurisdiction clause." 143

In interpreting the scope of jurisdiction agreements, the courts refer to the presumed intentions of the parties. For example, in Reinsurance Australia v HIH, Jacobson $\mathrm{J}$ held that it was "most unlikely that the parties intended a New York court to have jurisdiction in relation to an Australian statute [the TPA] which has no equivalent in that jurisdiction." 144

Although the issue has not been litigated often in Australia, there is authority that choice of court agreements are separable, and that any attack on the validity of the choice of court agreement must be directed to the choice of court agreement specifically, rather than the agreement as a whole. ${ }^{145}$ It is not often plausible for the plaintiff to raise such an argument, but in Commonwealth Bank of Australia v White, the defendant challenged the validity of the exclusive jurisdiction clause directly, asserting that the third party which had invoked the exclusive jurisdiction clause had procured the jurisdiction agreement with a view improperly to "shielding itself" from the effect of legislation, including the Australian Trade Practices Act and companies legislation, and that therefore the clause was void as being contrary to public policy, or unconscionable. ${ }^{146}$

\section{(ii) Non-exclusive Foreign Jurisdiction Clauses}

In Australian law, non-exclusive foreign jurisdiction agreements have a lower status than exclusive jurisdiction agreements, and are regarded as being merely one factor relevant to

\footnotetext{
143 Vetreria Etrusca Srlv Kingston Estate Wines Pty Ltd [2008] SASC 75, [21] (reference omitted). 144 Reinsurance Australia Corp v HIH Casualty and General Insurance (in liq) [2003] FCA 56, [349].

145 FAI General Insurance Co Ltd v Ocean Marine Mutual Protection and Indemnity Association (1997) 41 NSWLR 559, 567.

146 Commonwealth Bank of Australia v White [1999] 2 VR 681, [11].
} 
determining whether a stay should be granted on the basis of forum non conveniens. ${ }^{147}$ This is because commencing proceedings in a forum other than the chosen court is not inconsistent with the terms of the agreement, and therefore enforcing the agreement does not mandate declining jurisdiction in favour of the chosen court.

\section{(c) Empirical Analysis of Recent Cases}

In order to assess the effectiveness of the current Australian principle which regulates the enforcement of foreign jurisdictional agreements, it is instructive to consider the practices of the superior courts in jurisdictional disputes involving such agreements. In the period 2001-2008, there has been significantly less litigation in the Australian superior courts concerning the enforcement of jurisdiction agreements than there has been concerning the enforcement of international arbitration agreements. ${ }^{148}$ Since 2001, there have been only eight cases litigated involving the application of effective jurisdiction clauses. ${ }^{149}$ In these cases, the courts enforced the choice of court agreement in only one case. ${ }^{150}$

147 Eurogold Ltd $v$ Oxus Holdings (Malta) Ltd [2007] FCA 811, [44], [48], [60] per Siopsis J.

148 On LexisNexis' Casebase, Thomson's FirstPoint and Austlii databases, and using the search terms "Akai", "jurisdiction agreement", "jurisdiction clause", "foreign jurisdiction agreement", "foreign jurisdiction clause" fourteen cases were identified, of which seven were excluded for various reasons, including that the jurisdiction clause was held not to be exclusive (Autotrop SDN BHD v Powercrank Batteries Pty Ltd [2006] VSC 401), that the clause was held not to be incorporated into the contract (Heilbrunn v Lightwood plc (2007) 243 ALR 343), or where leave to appeal was refused because no error had been demonstrated in the exercise of the primary judge's discretion (The Society of Lloyd's $v$ White [2004] VSCA 101). Only seven cases remained after excluding the cases in which the courts did not consider that there was an effective jurisdictional agreement: Clough Engineering Ltd v Oil and Natural Gas Corporation Ltd [2007] FCA 881; Hume Computers Pty Ltd v Exact International BV [2006] FCA 1440; Incitec Ltd v Alkimos Shipping Corporation (2004) 138 FCR 496; Puccini Festival Australia Pty Ltd v Nippon Express (Australia) Pty Ltd (2007) 17 VR 36; Reinsurance Australia Corp v HIH Casualty and General Insurance (in liq) [2003] FCA 56; Vetreria Etrusca Srl v Kingston Estate Wines Pty Ltd [2008] SASC 75; Villasenor v The World of Residensea II Ltd [2007] FCA 647. In one of those cases, there were two separate foreign exclusive jurisdiction agreements, which are treated separately in the following analysis, which consequently refers to eight cases in total.

149 In a study of the disposition of jurisdiction disputes in the Australian superior courts between 1991 and 2001, there were 24 cases in which the effect of an exclusive jurisdiction agreement was in issue: Keyes, supra n 101, 163.

150 Villasenor v The World of Residensea II Ltd [2007] FCA 647; this case is unusual because the applicant in Australian proceedings sought only an interlocutory injunction, and accepted that after that injunction had taken its course, the proceedings would be permanently stayed in favour of the foreign jurisdiction agreement. 
The courts commonly referred to the factors identified as relevant in The 'Eleftheria'. In six cases, the plaintiff was Australian; whereas none of the first defendants (the party seeking enforcement) was Australian. ${ }^{151}$ The court referred to the location of evidence in only two cases, in which it held that the preponderance of evidence was to be found within the forum. The governing law was identified in five cases. In two of those cases, Australian legislation was held to be applicable, notwithstanding an otherwise effective choice of foreign law clause. The plaintiff included claims under Australian legislation in five of the eight cases. ${ }^{152}$ In four cases, the court explicitly concluded that the plaintiff would enjoy a legitimate juridical advantage in litigation in the forum because of the application of Australian legislation.

Although the number of cases is very small, several trends can be identified from the data. First, the courts were more likely to stay proceedings involving a foreign plaintiff than in cases involving a local plaintiff. ${ }^{153}$ Second, the courts were more likely to stay proceedings where there were no third parties involved. ${ }^{154}$ Third, where the court explicitly identified a legitimate advantage to the plaintiff of litigating in the forum, the court was less likely to stay proceedings than in cases in which no legitimate advantage was identified. ${ }^{155}$ Fourth, where the litigation involved claims under forum legislation, the court was less likely to stay proceedings. ${ }^{156}$ Finally, the place where the relevant activities which gave rise to the dispute between the parties occurred was related to

\footnotetext{
151 In a small number of cases, there were additional defendants - not parties to the jurisdiction agreement - who were Australian.

152 In five cases, claims under the Trade Practices Act 1974 (Cth) or equivalent legislation of the Australian States (in the State Fair Trading Acts) were included; three cases involved claims under the Australian Securities and Investments Commission Act 2001 (Cth); and one case each involved a claim under the Insurance Contract Act 1984 (Cth) and the NSW contribution legislation.

153 A stay was granted in one of the two cases in which the plaintiff was foreign $(50 \%)$, and in no case in which the plaintiff was local ( 0 of 6 cases).

154 A stay was granted in 33\% of cases in which there were no third parties ( 1 of 3 cases), and in no cases in which third parties were involved ( 0 of 5 cases).

155 Stays were granted in no cases in which the court identified a legitimate advantage ( 0 of 4 cases), and in $25 \%$ of cases in which no advantage was identified ( 1 of 4 cases).

156 Stays were granted in no cases including a claim under forum legislation ( 0 of 5 cases), and in $33 \%$ of cases which did not include such a claim ( 1 of 3 cases).
} 
outcomes. Where at least some of the activities occurred locally, the court granted a stay in no cases; ${ }^{157}$ but in the single case in which all the activities occurred abroad, the court granted a stay.

These results must be treated very cautiously, given the extremely small size of the sample. They indicate that the strategies of including third parties and non-contractual claims, especially claims under local legislation, are very effective in avoiding foreign jurisdictional agreements in Australian litigation. What is especially disturbing about this study is that the Australian courts have become less likely to enforce foreign jurisdictional agreements over time. In a study of cases decided by the Australian superior courts between 1991 and 2001, foreign jurisdiction agreements were enforced in 11 out of 19 cases. ${ }^{158}$ The data presented above show decisively that in the last seven years, the Australian courts were much less likely to give effect to exclusive foreign jurisdictional agreements than to international arbitration agreements. ${ }^{159}$

\section{(d) Conclusion}

Although the applicable principle suggests that derogation clauses should be enforced unless there are strong grounds for non-enforcement, in the vast majority of recent Australian cases, they have not been enforced. ${ }^{160}$ As demonstrated in the foregoing analysis, arbitration agreements are more likely to be enforced than jurisdictional agreements. It should be a matter of concern that the Australian courts' record in enforcing foreign choice of courts agreements in recent years has deteriorated. This very

\footnotetext{
157 Relevant activities occurred locally in three cases; both locally and abroad in two cases. The location of relevant activities was not specifically identified in two cases.

158 Keyes, supra n 101, 168.

159 Particular differences in these two studies show that the governing law has become a less important factor; that the availability of relief under s 52 Trade Practices Act 1974 (Cth) has become more important; that in the past there were proportionally more foreign plaintiffs, and fewer foreign defendants, and that it is more likely that the parties will specifically seek to identify the existence of juridical advantages in order to avoid enforcement: ibid, 163-168.

160 R Mortensen, Private International Law in Australia (Sydney, LexisNexis Butterworths, 2006), 102; Garnett, "The Enforcement of Jurisdiction Clauses", supra n 128, 9.
} 
clearly demonstrates the need for improvement to the Australian law on enforcing jurisdiction agreements. In the next section, the capacity of the Hague Choice of Courts Convention to contribute to this reform is critically considered.

\section{The Jurisdictional Principles in the Hague Choice of}

\section{Courts Convention}

The Hague Convention assumes that the scheme of the New York Convention can successfully be emulated in the context of international choice of court agreements. ${ }^{161}$ The Hague Convention is intended to protect autonomy and to provide predictability and certainty in international trade and commerce. ${ }^{162}$ In the following discussion, the jurisdictional provisions of the Hague Convention are discussed, in order to establish the extent to which they differ from the current Australian law, and whether they are likely to improve the practices of the Australian courts.

The Convention applies to a sub-set of international commercial disputes. It only applies to civil and commercial disputes in which the parties have concluded an exclusive choice of courts agreement. ${ }^{163}$ The Convention expressly excludes a significant number of matters from its scope; most significantly consumer and employment contracts, ${ }^{164}$ and a number of other matters, only some of which seem naturally related to disputes arising from a contract. ${ }^{165}$ Most relevantly, for the purposes of this discussion, the subject matter exceptions include "anti-trust (competition)" matters. ${ }^{166}$ Section 52 of the

\footnotetext{
161 A Schultz, "The Hague Convention of 30 June 2005 on Choice of Court Agreements" (2006) 8 European Journal of Law Reform 77, 92 (Schultz, “The Hague Convention of 30 June 2005”); A Schultz, "The 2005 Hague Convention on Choice of Court Clauses" (2005) 12 ILSA Journal of International and Comparative Law 433, 433 (Schultz, "The 2005 Hague Convention").

162 Hague Convention, Preamble; Schultz, "The Hague Convention of 30 June 2005", ibid, 92;

Schultz, “The 2005 Hague Convention”, ibid, 437.

163 Art.1.

164 Art.2(1).

165 Art.2(2).

166 Art.2(2)(h).
} 
Australian Trade Practices Act is, as discussed above, commonly relied on in Australian international litigation. Although it is contained in legislation dealing with competition matters, and at least in domestic litigation, is often invoked by competitors, it is really a statutory version of misrepresentation and it is in that context that it is invoked in international litigation. It is likely that claims under section 52 would not be characterised as anti-trust matters, ${ }^{167}$ so section 52 claims are likely to be invoked in litigation in which the Convention is potentially applicable.

\section{Differences Between the Convention and the Current Australian Law}

The Convention, if implemented, would refine and improve many aspects of the current Australian law on choice of courts agreements. The Convention deems that a choice of courts agreement is exclusive, unless the parties "have expressly provided otherwise". ${ }^{168}$ This differs from the Australian law, under which there is presently no such presumption. As stated above, Australian writers would welcome this change. ${ }^{169}$

The Convention appropriately recognises that prorogation clauses should be treated similarly to derogation clauses. The first aspect of the Convention establishes the obligations of the chosen court. It appears that the Convention is intended to impose an obligation on the chosen court to hear cases unless the agreement is null and void. ${ }^{170}$ The manner in which Article 5(1) is expressed is unfortunate. It appears to confer personal jurisdiction on the chosen court, rather than positively to impose an obligation on the chosen court to hear cases. This ambiguity may give rise to litigation. The better view is that there is an obligation on the chosen court to exercise jurisdiction, unless one of the exceptions in Article 5(2) applies, or unless a declaration has been made under

\footnotetext{
167 T Hartley and M Dogauchi, Explanatory Report on the Convention of 30 June 2005 on Choice of Court Agreements (The Hague, Permanent Bureau of the Hague Conference on Private International Law, 2007, available at http://www.hcch.net/upload/expl37e.pdf, last accessed 22 September 2008), 32.

168 Art.3(b).

169 Garnett, "The Enforcement of Jurisdiction Clauses"supra n 128, 5-9; Keyes, supra n 101, 97

$170 \quad$ Art.5(1); Hartley and Dogauchi, supra n 167, 21, 42-43.
} 
Article $19 .{ }^{171}$ Article 5(2) states that the chosen court cannot decline jurisdiction on the basis that a foreign court should determine the dispute. This is intended to preclude reference to the principle of forum non conveniens, and to any consideration of parallel proceedings. ${ }^{172}$ This would change the current Australian law, although in practice it is unlikely that it would change the outcome of many cases. Considering the increased prominence which has been given in recent cases to the objective of preventing fragmentation of disputes, depriving the courts of their discretion in this way may stimulate the development of creative arguments in practice.

The Convention enacts separability of choice of court agreements. ${ }^{173}$ There is Australian authority suggesting that jurisdiction agreements are separable, ${ }^{174}$ so this provision would not significantly change the current Australian law, although it would place the principle on a more secure footing. It can be anticipated that direct attacks on jurisdictional agreements will become more common. ${ }^{175}$

The second aspect of the Hague Convention's scheme is that the non-chosen court is obliged to stay proceedings brought in breach of the agreement. The Convention deprives the non-chosen court of the discretion whether to retain jurisdiction, if the criteria of application are satisfied and none of the exceptions apply. ${ }^{176}$ This aspect of the Convention is controversial, from an Australian perspective. Compared to recent developments in other common law jurisdictions, the Australian courts have actively asserted their authority to determine whether jurisdiction should be retained in

\footnotetext{
171 Article 19 permits a State to "declare that its courts may refuse to determine disputes to which an exclusive choice of court agreement applies if, except for the location of the chosen court, there is no connection between that State and the parties or the dispute."

172 Hartley and Dogauchi, supra n 167, 21, 44.

173 Art.3(d).

$174 \quad$ FAI General Insurance Co Ltd v Ocean Marine Mutual Protection and Indemnity Association (1997) 41 NSWLR 559.

175 Briggs, supra n 2, 530.

176 Art.6.
} 
international litigation, and are significantly more likely than the courts of other countries to retain jurisdiction, notwithstanding an otherwise effective derogation agreement.

The Convention allows the non-chosen court to retain jurisdiction in five cases, ${ }^{177}$ which are based on, but narrower than, the exceptions under the New York Convention. These are where the agreement is null and void according to the law of the state of the chosen court; ${ }^{178}$ where one party lacked contractual capacity under local law; ${ }^{179}$ where giving effect to the agreement would "lead to a manifest injustice or would be manifestly contrary to the public policy" of the local law; ${ }^{180}$ where the agreement "cannot reasonably be performed", but only for "exceptional reasons beyond the control of the parties"; ${ }^{181}$ and where the chosen court has decided not to hear the case. ${ }^{182}$ Requiring the enforcement of choice of court agreements, subject only to these limited exceptions, would very substantially modify the Australian law.

These exceptions can be divided into two groups. The first group contains the exceptions which attempt to ensure that the parties are not deprived of a fair hearing, by protecting the parties from any "manifest injustice" that might result from the enforcement of their agreement, and by providing a forum in the unlikely event that the chosen court has declined to hear the case. The second group of exceptions are based upon, but significantly reduce, the exceptions which apply under the New York Convention. These are where the choice of court agreement is null and void; where its

\footnotetext{
177 Art.6.

178 Art.6(a).

179 Art.6(b). This exception seems most unlikely to arise in international commercial disputes, and consequently is not discussed any further below.

180 Art.6(c).

181 Art.6(d)

182 Art.6(e). This exception is puzzling, and seems inconsistent with Art.5. Art.5 states that the only circumstance in which jurisdiction can be declined by the chosen court is if the chosen court holds that the agreement is null and void. This exception is already included in Art.6(a), and so Art.6(e) seems to be redundant. It is intended to "avoid a denial of justice: it must be possible for some court to hear the case.": Hartley and Dogauchi, supra n 167, 48.
} 
enforcement would contravene the forum's public policy; and where the choice of court agreement cannot be performed.

The first group of exceptions are relatively uncontroversial, and seem unlikely to be raised in practice. It is unusual for chosen courts to decline to exercise jurisdiction; in the unlikely event that a chosen court declines jurisdiction, it is of course essential to preserve the parties' entitlement to a hearing. The exception which permits nonenforcement of a choice of courts clause where to do so would lead to manifest injustice is intended to refer, for example, to situations in which one of the parties could not get a fair trial in foreign proceedings. ${ }^{183}$ This does not differ from the current Australian law, which presently permits reference to this consideration as one of the factors identified by Brandon $\mathrm{J}$ in The Eleftheria ${ }^{,}{ }^{184}$ Although Bell criticised the other factors identified by Brandon J, he correctly accepted that the non-availability of a fair trial in the chosen court is a sound justification for non-enforcement of jurisdictional agreements. ${ }^{185}$

However, the injustice exception is unlikely to be successful, even if raised, in Australian litigation. The Australian courts do not look favourably on arguments that jurisdiction should be retained because of perceived shortcomings in the foreign legal system. In Voth v Manildra Flour Mills, the High Court held that there were "powerful policy considerations which militate against Australian Courts sitting in judgment upon the ability or willingness of the courts of another country to accord justice to the Plaintiff in

\footnotetext{
183 Hartley and Dogauchi, ibid.

184 The 'Eleftheria' [1970] P 94, 100.

185 Bell, supra n 4, 328.
} 
the particular case". ${ }^{186}$ In most cases in which concerns about the quality of litigation in foreign courts are raised, the courts have refused to take this factor into account. ${ }^{187}$

As Garnett suggests, it is also possible that Australian courts may hold that a loss of the right to claim under Australian legislation, which would be a consequence of the enforcement of a choice of court agreement, amounts to a "manifest injustice" which warrants non-enforcement of the agreement. ${ }^{188}$

The narrow scope of the second group of exceptions would be likely to lead to more regular enforcement of choice of court agreements, if the Convention were implemented in Australia. The exception which permits non-enforcement if the choice of court agreement is null and void specifies that this issue must be determined by the law of the chosen court. ${ }^{189}$ This stipulation differs from the Australian common law, which unjustifiably requires application of forum law to determine the validity of jurisdictional agreements. ${ }^{190}$

The public policy exception "is intended to set a high threshold". ${ }^{191}$ The official commentary on this provision is unfortunately brief and does not clearly state whether statutes which are regarded as having internationally mandatory effect are intended to be included in this exception. ${ }^{192}$ Recent cases suggest that in Australian litigation, the potential non-application of section 52 of the Trade Practices Act by a foreign court

\footnotetext{
186 Voth $v$ Manildra Flour Mills Pty Ltd (1990) 171 538, 559, referring to Attorney-General (UK) $v$ Heinemann Publishers Australia Pty Ltd (1988) 165 CLR 30.

187 Seereederei BACO Liner Gmbh v Owners of the Ship 'Al Aliyu' [2000] FCA 656, [23]-[24]; Pertsch v PT John Holland Constructions Indonesia [2001] QSC 127, [11]-[13]; CTA International Pty Ltd v Sichuan Changhong Electric Co Ltd [2002] VSC 374, [14]. Cf Toop v Mobil Oil New Guinea Ltd [1999] VSC 11, [31]-[32].

188 R Garnett, "The Hague Choice of Court Convention: Magnum Opus or Much Ado about Nothing?”, (2009) 5 Journal of Private International Law 161, 166-167 (Garnett, "The Hague Choice of Court Convention"). See similarly R Garnett, "The Internationalisation of Australian Jurisdiction and Judgments Law" (2004) 25 Australian Bar Rev 205, 216 (Garnett, “The Internationalisation”).

189 Art.6(a).

190 Oceanic Sun Line Special Shipping Co Inc v Fay (1988) 165 CLR 197, 225 per Brennan J, 260-1 per Gaudron J. Wilson and Toohey JJ applied the lex fori to this issue without explaining why (at 202); Deane J agreed with Wilson and Toohey JJ on this point (at 256). Cf Garnett, "The Internationalisation" supra n 188,214 (stating that this issue is governed by the proper law of the contract).

191 Hartley and Dogauchi, supra n 167, 48.

192 See Garnett, “The Hague Choice of Court Convention”, supra n 188, 166-7.
} 
would be regarded as manifestly incompatible with Australian public policy. ${ }^{193}$ The public policy exception is likely to be a focus of attempts to avoid choice of courts agreements, if the Convention is implemented in Australia.

Whereas the New York Convention allows that arbitration agreements may not be enforced if they are "incapable of being performed", the Hague Convention only allows non-enforcement if the agreement cannot be performed because of "exceptional reasons beyond the control of the parties". This is intended to apply only in the most unusual of circumstances; according to the Hartley/Dogauchi Report, it is akin to the common law doctrine of frustration. ${ }^{194}$ This exception seems unlikely to be invoked in practice.

There are two important differences between the Hague Convention and the New York Convention which are material to the current discussion. First, the Hague Convention does not allow non-enforcement when the agreement is inoperative. In the case of arbitration agreements, this applies where the parties have mutually or unilaterally abandoned the agreement. It is entirely foreseeable that this might occur in the choice of courts context, and yet no exception unambiguously extends to this prospect. ${ }^{195}$ Second, the New York Convention specifically allows the court to stay only the part of the proceeding to which the arbitration agreement applies, whereas the Hague Convention evidently would require the court to stay the entire proceeding. ${ }^{196}$ Both of these matters have been shown to arise commonly in practice, and therefore should have been dealt with directly in the Hague Convention.

\footnotetext{
193 Akai Pty Ltdv The People's Insurance Co Ltd (1996) 188 CLR 418; Clough Engineering Ltd v Oil and Natural Gas Corporation Ltd [2007] FCA 881; Hume Computers Pty Ltd v Exact International BV [2006] FCA 1440; Commonwealth Bank of Australia v White [1999] 2 VR 681; The Society of Lloyd's v White [2004] VSCA 101.

$194 \quad$ Hartley and Dogauchi, supra n 167, 48.

195 Of course, the parties may by later agreement vary their agreement as to exclusive choice of court. If such a variation is established, the consequence would be that the original exclusive choice of court agreement no longer existed and therefore Art.6 would not apply to it.

196 Art.6. Alternatively, it might be argued that Art.6 only requires a stay to be granted if every aspect of the proceedings is subject to the choice of courts clause. It could also be argued that Art.6 requires a stay to be granted only of the part of the proceeding to which the choice of court agreement applies.
} 


\section{Summary}

The Convention's objective to remove much of the courts' discretion in deciding whether to enforce the agreements of the parties is similar to the New York Convention. ${ }^{197}$ Briggs observed that these instruments all

"provide for the mechanical enforcement of an agreement to arbitrate or adjudicate even where this has a fragmenting effect on the overall resolution of complex disputes. Opinions will legitimately differ on whether this is a desirable outcome; it is not the approach which has commended itself to the common law."'198

One suspects that the common law's deep-seated discomfort with the mechanical enforcement of rules, and preference for the ability to exercise the discretion to do justice in all the circumstances, might account for the fact that a stay was not granted in seven out of 17 recent Australian cases on enforcing the New York Convention. It suggests that the Australian courts are not likely to achieve $100 \%$ compliance with the Hague Convention, if it is implemented in Australian law.

Briggs recently noted that "the Convention is, from an English perspective, modest. One would think it was hard to imagine that the private international law of any mature legal system is very far removed from this state of development". ${ }^{199}$ In Australia, the Convention should have a more significant impact. As discussed above, Australian courts have not improved in their treatment of jurisdiction agreements in recent years, and this is a matter that requires attention. Although there are some potential problems with the Hague Convention, it is likely to result in choice of courts agreements being enforced more frequently, a highly desirable outcome.

\footnotetext{
197 It resembles also the scheme of the Brussels I Regulation: Briggs, supra n 2, 531.

$198 \quad$ Ibid, 531.

$199 \quad$ Ibid, 529.
} 


\section{E CONCLUSION}

Both the New York Convention and the Hague Convention employ simple rules requiring enforcement of agreements on arbitration and choice of courts, with limited exceptions permitting non-enforcement. This is intended to achieve important commercial purposes. This strategy has been relatively successful in Australia, in the context of the enforcement of international arbitration agreements. The Australian law on the enforcement of choice of courts agreements gives insufficient weight to the importance of upholding the parties' agreements. This is compounded by the way in which the principle is applied in practice. The Australian courts' recent practice in the treatment of choice of courts agreements has been poor, and this is a matter which requires urgent attention. The Hague Convention, if it is implemented in Australia, should increase the likelihood that choice of court agreements are enforced.

The analysis in this article shows that there are limits to which the Australian judiciary is prepared to give effect to this strategy, above all other concerns. In particular, Australian courts are concerned to ensure the efficient disposition of disputes, as well as with the public interests implicit in dispute resolution. Consequently, like the New York Convention, the Hague Convention is unlikely to be fully effective in litigation in Australian courts. 